\title{
THE DEVELOPMENT AND VALIDATION OF THE PENTA HELIX CONSTRUCT
}

\author{
Kiki SUDIANA ${ }^{1 *}$, Erni Tisnawati SULE ${ }^{2}$, Imas SOEMARYANI ${ }^{3}$, Yunizar YUNIZAR ${ }^{4}$ \\ ${ }^{1}$ Faculty Economy and Business, Telkom University, Bandung, Indonesia \\ 2, 3, ${ }^{4}$ Faculty of Economy and Business, Universitas Padjadjaran, Bandung, Indonesia
}

Received 22 September 2019; accepted 05 January 2020

\begin{abstract}
The concept of Penta Helix or Quintuple Helix have been widely discussed and used as frameworks in many researches in relation of innovation or organizational innovation field. it is believed that if the Penta Helix stakeholders work together in synergy it will foster innovation and an innovation-based economy. However, no research has been found yet that validate measurement constructs of the Penta Helix or the Quintuple Helix. Through extensive literature review, we developed a construct of the Penta Helix variables in relation to innovation and knowledge-based economy, into five dimensions consisting of Academicians, Business, Government, Community and Medias (ABGCM). The data was collected through a questionnaire distributed to 95 technology-based startups in Indonesia, and afterward analysed by using confirmatory factor analysis technique, performed by the SmartPLS software. A final 20-item measurement construct was validated as main contribution of this study toward Penta Helix theory. There are issues arose on methodological and theoretical of the Penta Helix construct and discussed in our findings.
\end{abstract}

Keywords: Penta Helix Construct, confirmatory factor analysis, construct validity, Validity Penta Helix.

JEL Classification: A13, C31, C52, O32, L26.

\section{Introduction}

The concept of Penta Helix originally coming from Triple Helix theory that believed a strong Triple Helix relationship of Academicians, Business and Government (ABC) will encourage innovation both economically and scientifically (Etzkowitz \& Leydesdorff, 1997). Furthermore, the Triple Helix concept was developed into a Quadruple Helix with the addition of Medias as the 4th helix (Carayannis \& Campbell, 2010; Ivanova, 2014; Leydesdorff, 2012a) then developed again into the Penta (Quintuple) Helix (Carayannis, Barth, \& Campbell, 2012; Fyodorov, Peshina, Gredina, \& Avdeev, 2012; Halibas, Sibayan, Lyn, \& Maata, 2017; Tonkovic et al., 2015; E. Veckie \& V. W. Veckie, 2014).

However, it appears that the theoretical concept and construct of the Quadruple Helix and the Penta (quintuple) Helix are not yet mature, this can be seen from the differences in the proposed fourth and fifth helix, having seen the tendency in many previous studies that directly use the Penta Helix in a qualitative research framework without seeing conclusions whether the concept has been validated or not. The quadruple helix concept proposed by Carayannis and Campbell (2010), Leydesdorf (2012a), Ivanova (2012) and is intended to be a conceptual framework to support innovation, that was proposed without empirical validation. Furthermore, the concept of the Quintuple Helix Innovation model was developed by Carayannis et al. (2012), this model was used as a framework for analyzing drivers of innovation which also proposed without prior empirical validation. Subsequently some researchers use the Penta Helix model as a framework to analyze the roles that must be performed by stakeholders to support innovation in Universities (Sibayan et al., 2017), to support actors of creative economy (Muhyi et al., 2014), and economic development in the region (Tonkovic et al., 2015) without considering that the framework they were using was not validated yet. This research is intended to build a construct of the Penta Helix for researches context regarding innovation that is complemented by the validity and reliability of the construct using the Confirmatory Factor Analysis method.

${ }^{*}$ Corresponding author. E-mail: ksudiana@telkomuniversity.ac.id 


\section{Theoretical development of the Penta Helix}

The Penta Helix concept was formed around the development of two innovative model, namely from the Triple Helix theory, subsequently developed into the Quadruple Helix, and then into the Penta Helix. The development of the Triple Helix relationship model between Academicians, Industry and Government was initiated by Etzkowitz and Loet Leydesdorff in 1997, they developed this model in the claim that there was a shift from the dual helix model (industry-government) or the relationship between Industry - University, to the relationship between 3 helix, namely: (1) Government, (2) Industry / Business and (3) University / Higher Education (Etzkowitz \& Leydesdorff, 1997).

The Triple Helix model related to economic development is a development of the initial theory of economic development proposed by Schumpeter (1934) which states that there are 2 basic actors of economic development namely entrepreneurs and innovators (2 helix). The model was developed in relation to the economic evolution that occurred based on innovation and economic development in a knowledgeable society portrayed by a developing technology and knowledge-based startups (Etzkowitz \& Leydersdoff, 1997). The definition of the Triple Helix made by Ranga and Etzkowitz (2013) is that the Triple Helix system is a set of: (i) the institutional component of University, Industry and Government, which has a variety of roles; (ii) relationships between components (collaboration and conflict moderation, collaborative leadership, substitution and networking), and (iii) functions, which describe the processes that occur in what are referred to as' Knowledge, Innovation and shared space (consensus spaces)' (Ranga \& Etzkowitz, 2013)

Critics on the triple helix concept arisen because this concept ignores the role of the community in innovation projects developed by government-industry-academia (Fyodorov et al., 2012), criticism that lead to the development of the triple helix into the Quadruple Helix. This Quadruple helix concept is a development of the triple helix model by integrating civil society as the fourth helix (Afonso, Monteiro, \& Thompson, 2012) the Quadruple helix theory is an interaction of four sectors, namely: Government, Business, Academia, and Civil society that play a role in encouraging innovation.

Furthermore, in the process of developing the model, the Quadruple helix was developed into the Penta Helix. The Penta helix is a conceptual framework involving academicians, government, industry, non-governmental institutions, civil society, or social entrepreneurs or media that believed able to enhance economy to pursue innovation and entrepreneurship through collaboration and synergy (Fyodorov et al., 2012; Halibas et al., 2017; Muhyi et al., 2017; Tonkovic, Veckie, \& Veckie, 2015). In relation to entrepreneurial universities, collaboration among penta helix stakeholders is believed to encourage the growth and development of startups and spinoff companies from universities (Guerrero \& Urbano, 2019) as well as small medium enterprises and public cooperatives (Yahya, Santoso, \& Wanto, 2018). Yet there are several versions of Penta Helix stakeholders but none of them are validated empirically.

\section{The Penta Helix of innovation's construct}

In their theoretical framework study, researchers have pointed out the importance of the synergy relationship between the three helix components to interact and work together, where the interaction between the three components would bring new knowledge and innovation, and also creates the dynamics of innovation-based economic activities (Etzkowitz \& Leydesdorff, 1997; Rampersad, Quester, \& Troshani, 2010).

However, the Penta Helix model developed by researchers has different components. In relation to economic and social development Halibas et al. (2017) have offered a Penta Helix component consisting of: 1) academicians who are able to encourage and enable the dissemination of ideas and implementation of innovation and entrepreneurship, 2) the government who plays a role in supporting innovation systems through public investment in terms of research and development as well as knowledge infrastructure, public innovation policies, and support for innovation by partnering/networking with private institutions, 3) Private support through funding of research and product development commercialization technics. On the contrary, the private sector actually benefits from the existence of new technology from research findings, and finally 5) Non-governmental institutions and civil society that are expected to be involved in social and economic development through active participation in development programs using the Penta helix model (Halibas et al., 2017).

Carayannis and Campbell (2010) have developed a Quintuple Helix Model of Innovation framework with components as follow: (1) Academicians, (2) Business, (3) Government, (4) "Medias", "creative industries", "culture", "values", "Lifestyles", "art", or "creative class" and (5) natural environment as the fifth helix (Carayannis, Barth, \& Campbell, 2012). On the other hand, Calzada (2017) in Halibas et al. (2017) have proposed a Penta Helix Model of Innovation framework with components such as: (1) Academics, (2) Government, (3) Private (4) Civil Society and (5) Social Entrepreneurs (Carayannis et al., 2012)

In contrast to other previous studies, Tonković et al. (2015) have proposed different Penta Helix components in the context of economic development. According to them, the Penta Helix components consist of: (1) Academics, (2) Entrepreneurs, (3) Government, (4) Non-Governmental Organizations and (5) Diaspora (Tonkovic et al., 2015).

In relation to the development of creative industry in Indonesia, Awaluddin et al. (2016) have stated that the Penta helix plays an important role in ensuring industrial creativity and value creation. The Penta Helix developed by Awaludin et al. (2016) consists of: 1) Academics, 2) Business, 3) Government, 4) Medias and 5) Community. 
However, the concept of this Penta Helix developed by Awaludin is not supported by empirical studies and statistical data processing that map out the relationship and support of each helix to the creative industry of startups (Awaluddin, Sule, \& Kaltum, 2016).

Different from several studies regarding the Penta Helix issue which was adapted to the context of research on the innovativeness of startups, in this present study, what is meant by Penta Helix is variable such as the support and activities of Academics, Business, Government, Community, and Medias as well as the interactions between these variables in fostering Organizational Innovation and Product Innovation Performance for Startups.

The various constructs of the Penta helix, as well as construct that beig used in this study are shown in Table 1.

In this research, Penta Helix is defined as Collaboration among stakeholders consist of Academicians, Business,
Government, Community and Media (ABGCM) in order to develop innovation and innovation-based economy. Referring to the dimensions used in previous researches and also to the context in this research that is looking for dimensions that are relevant to the support that can be provided by stakeholders of the Penta Helix concept to increase the innovation power of startups, the construct dimensions of the Penta Helix variables in this study are:

- Academicians: Academicians contributes to the development of human resources such as graduates, lecturers, researchers which play an important role in the usage of knowledge and research into innovation and also new products/businesses (Carayannis et al., 2012)

- Business: The term "Business" can be interpreted as a business person or entrepreneur. This subsystem is expected to contribute to a knowledge-based econ-

Table 1. Dimensions of the Penta helix measurement in previous researches

\begin{tabular}{|c|c|c|c|c|c|c|c|c|}
\hline Researcher \& Research Context & 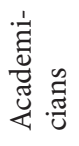 & $\underset{\mathscr{Q}}{\mathscr{\Xi}}$ & 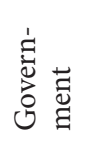 & 芑 & 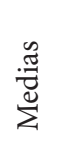 & 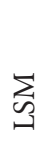 & $\begin{array}{l}\frac{\pi}{0} \\
\stackrel{0}{0} \\
\stackrel{\tilde{a}}{0}\end{array}$ & 胥 \\
\hline $\begin{array}{l}\text { (Dhewanto et al., 2014) } \\
\text { The Triple Helix dimension in the context of } \\
\text { research in relation with innovation }\end{array}$ & $\mathrm{X}$ & $\mathrm{X}$ & $\mathrm{X}$ & & & & & \\
\hline $\begin{array}{l}\text { (Leydesdorff, 2012b) } \\
\text { The Triple Helix dimension in the context of } \\
\text { research in relation with innovation }\end{array}$ & $\mathrm{X}$ & $\mathrm{X}$ & $\mathrm{X}$ & & & & & \\
\hline $\begin{array}{l}\text { ( Leydesdorff \& Park, 2014) The Triple Helix } \\
\text { dimension in relation with innovation }\end{array}$ & $\mathrm{X}$ & $\mathrm{X}$ & $\mathrm{X}$ & & & & & \\
\hline $\begin{array}{l}\text { (Leydesdorff, 2012a) } \\
\text { The Quadruple Helix dimension in relation with } \\
\text { innovation }\end{array}$ & $\mathrm{X}$ & $\mathrm{X}$ & $\mathrm{X}$ & $\mathrm{X}$ & & & & \\
\hline $\begin{array}{l}\text { (Parveen, Senin, \& Umar, 2015) } \\
\text { The Quadruple Helix dimension in relation with } \\
\text { innovation }\end{array}$ & $\mathrm{X}$ & $\mathrm{X}$ & $\mathrm{X}$ & $\mathrm{X}$ & & & & \\
\hline $\begin{array}{l}\text { (Campbell et al., 2015) } \\
\text { The Quadruple Helix dimension in relation with } \\
\text { innovation }\end{array}$ & $\mathrm{X}$ & $\mathrm{X}$ & $\mathrm{X}$ & & $\mathrm{X}$ & $\mathrm{X}$ & & \\
\hline $\begin{array}{l}\text { (Ivanova, 2014) The Quadruple Helix dimension in } \\
\text { the context of research has to do with innovation }\end{array}$ & $\mathrm{X}$ & $\mathrm{X}$ & $\mathrm{X}$ & & $\mathrm{X}$ & & & \\
\hline $\begin{array}{l}\text { (Awaluddin et al., 2016) The Penta helix dimension } \\
\text { in research on digital startup }\end{array}$ & $\mathrm{X}$ & $\mathrm{X}$ & $\mathrm{X}$ & $\mathrm{X}$ & $\mathrm{X}$ & & & \\
\hline $\begin{array}{l}\text { (Kockum, Franzén, \& Martini, 2010) } \\
\text { The Penta helix dimension is in the context of } \\
\text { research on the performance of SMEs }\end{array}$ & $\mathrm{X}$ & $\mathrm{X}$ & $\mathrm{X}$ & $\mathrm{X}$ & & $\mathrm{X}$ & & \\
\hline $\begin{array}{l}\text { (Tonkovic et al., 2015) } \\
\text { The Penta helix dimension in the context of } \\
\text { research on Economic Growth }\end{array}$ & $\mathrm{X}$ & $\mathrm{X}$ & $\mathrm{X}$ & & & $\mathrm{X}$ & $\mathrm{X}$ & \\
\hline $\begin{array}{l}\text { Halibas et al. (2017) } \\
\text { The Penta helix dimension is in the context } \\
\text { of research on business and environmental } \\
\text { sustainability }\end{array}$ & $\mathrm{X}$ & $\mathrm{X}$ & $\mathrm{X}$ & $\mathrm{X}$ & & $\mathrm{X}$ & & \\
\hline $\begin{array}{l}\text { Calzada (2016) } \\
\text { The Penta helix dimension is in the context } \\
\text { of research on business and environmental } \\
\text { sustainability }\end{array}$ & $\mathrm{X}$ & $\mathrm{X}$ & $\mathrm{X}$ & $\mathrm{X}$ & & $\mathrm{X}$ & & \\
\hline The construct of this research & $\mathrm{X}$ & $\mathrm{X}$ & $\mathrm{X}$ & $\mathrm{X}$ & $\mathrm{X}$ & & & \\
\hline
\end{tabular}


omy in the form of "venture capital" and the ability to run a business. This is in line with what was expressed by (Carayannis et al. 2012). The role of this helix is to support startup innovation, among others, with capital support, networking, business cooperation and CSR.

- Government: Government has the authority in the field of law and public policy, in this case, Indicators of the government dimension are related to "political and legal capital" from the government namely: permits, policies, incentives, grants that can be allocated for the development of startup innovations and also the provision of basic infrastructure such as electricity, water, access roads and others (Etzkowitz \& Leydesdorff, 1997; Fathin, 2016; Katili, Arbie, \& Uno, 2012).

- Community: as the fourth helix, the variable community has a role in supporting the innovativeness of startups through creating a forum for interaction within the community and enhancing their creative skills (Awaluddin et al., 2016). The community is one source of innovative product development ideas (Nylander \& Tholander, 2017) and also a vehicle for sharing ideas and developing innovation (Lindtner, Hertz, \& Dourish, 2014). Therefore, community involvement in the Penta helix scheme has an important role besides academics, business, and government, communities have the ability to participate directly in fostering innovation and a knowledgebased economy. Communities can directly conduct research and get feedbacks regarding new products issued by entrepreneurs through existing non-gov- ernmental organizations as community representatives, or directly through the community itself.

- Medias: have a role in conveying information relating to all kind of variables needed by different stakeholders. Journalists are positioned to cover and inform stakeholders. Publicity must aim to educate the public. The medias are also a channel for feedback and interaction between relevant stakeholders (Effendi et al., 2016). In addition, the medias play a role in connecting all the main actors with national and global industrial markets. Specifically, the medias are able to play an important role in ensuring that a company's reputation in Indonesia for example can remain the same in other developed countries (Awaluddin et al., 2016). The indicator of media support in this dimension can be seen from the aspect of publicity that medias does for startups and their products, the extent to which startups get ideas, informations regarding the voices and choices of customers and other useful informations channelled via medias and the level of intensity of communication between startups and stakeholders that is also wired through medias.

The dimensions and indicators of these Penta helix variables are summarized in the following Table 2.

\section{Methodology}

To represent the five dimensions of the Penta Helix model, 18 questions items were developed as listed in Appendix 1 based on the references in Table 2 and in accordance with our research context. We then the questionnaire

Table 2. Construction of the dimensions of the Penta Helix variables from several researches

\begin{tabular}{|c|l|l|}
\hline No & \multicolumn{1}{|c|}{ Dimensions \& References } & \multicolumn{1}{|c|}{ Number \& Indicator (item) } \\
\hline 1 & $\begin{array}{l}\text { Academicians } \\
\text { (Dhewanto et al., 2014; Leydesdorff, 2012b; Leydesdorff \& } \\
\text { Park, 2014, Leydesdorff, 2012a; Parveen, Senin, \& Umar, } \\
\text { 2015) }\end{array}$ & $\begin{array}{l}\text { PH11 - Number of educated HR (graduates) } \\
\text { PH12 - Research quality from campus } \\
\text { PH13 - Distance from campus }\end{array}$ \\
\hline 2 & $\begin{array}{l}\text { Business } \\
\text { (Dhewanto et al., 2014; Leydesdorff, 2012b; Leydesdorff \& } \\
\text { Park, 2014, Leydesdorff, 2012a; Parveen, Senin, \& Umar, } \\
\text { 2015) }\end{array}$ & $\begin{array}{l}\text { PH21 - Loan capital support } \\
\text { PH22 - Investment cooperation } \\
\text { PH23 - Business interactions / transactions } \\
\text { PH24 - CSR from business entities }\end{array}$ \\
\hline 3 & $\begin{array}{l}\text { Government } \\
\text { (Dhewanto et al., 2014; Leydesdorff, 2012b; Leydesdorff \& } \\
\text { Park, 2014, Leydesdorff, 2012a; Parveen, Senin, \& Umar, } \\
\text { 2015) }\end{array}$ & $\begin{array}{l}\text { PH31 - Licensing } \\
\text { PH32 - Pro SME Policy } \\
\text { PH33 - Taxation and retribution } \\
\text { PH34 - Aid and other Grant }\end{array}$ \\
\hline 4. & $\begin{array}{l}\text { Community } \\
\text { (Awaluddin et al., 2016, Kockum et al., 2010) }\end{array}$ & $\begin{array}{l}\text { PH41 - Community adoption in Startup products } \\
\text { PH42 - Community input / information on Startup products } \\
\text { / businesses } \\
\text { PH43 - Supply HR and other business needs from the } \\
\text { community }\end{array}$ \\
\hline 5. & $\begin{array}{l}\text { Media } \\
\text { (Campbell et al., 2015; Ivanova, 2014, Awaluddin et al., 2016; ; } \\
\text { Effendi et al., 2016) }\end{array}$ & $\begin{array}{l}\text { PH51 - Publicity by medias } \\
\text { PH52 - Ideas, voice of customers and other useful } \\
\text { information from medias } \\
\text { PH53 - Startup communication with stakeholders through } \\
\text { the medias }\end{array}$ \\
\hline
\end{tabular}


was developed in the way that it covers closed questions, with answer choices using a five-point Likert ordinal scale where answers are ranging from (1) Very Poor to (5) Very Good. The reason behind using a 5-point Likert scale is to be able to give to the respondents easier choices while still having a degree of point differentiation is that, the selection of categories in the questionnaire would be more specific, the strength of discrimination would be better, and there is a good stability (Budiaji, 2013).

The questionnaire (Figure 1,2) was distributed to 95 founders and startups managers in 9 cities throughout Indonesia, $70.5 \%$ of them are founders or Chief level (CEO, $\mathrm{COO}, \mathrm{CTO}, \mathrm{CMO}$ etc) and the rest $29.5 \%$ are managers of the startup. The startups run in various technology-based business, ranging from cosmetics, herbal medicines, food processing, vaccines, software, Internet of Things, Artificial Technology, Nano technology and others. Business tenure of the startups ranging 1 to 10 years, none of them are in the business more than 10 years.

Startups were chosen as units of analysis because startups are considered as important players in the innovation process and also the use of research and technology results for commercial purposes (Spender et al., 2017). While founders and startup managers are chosen to be observation units because they are considered to have adequate knowledge about the information to be extracted.

Measurement of the validity and reliability of the constructs of the dimensions and indicators (items) forming the latent construct of the Penta Helix is done by conducting Confirmatory Factor Analysis (CFA). This confirmatory factor analysis (CFA) is known as a statistical tool that is useful for testing a variable theory of manifests or indicators that build it, where the variable is assumed to only be measured by these indicators (Latan \& Ghozali, 2012). In other words, this test is used to perform model measurements in order to illustrate how well the aspects and indicators can be used as measurements of the Penta Helix construct variables.

The CFA test above is interpreted by looking at the loading factor value $(>0.5)$ and the calculated value of $t(>1.96)$. A loading factor value of 0.50 or more is considered to have a strong enough validity to explain latent constructs (Gozali, 2008; Hair Jr, Hult, Ringle, \& Sarstedt, 2016) while Sharma (1996) had explained that the weakest acceptable loading factor value is 0.40 . Hair et al. (2016) have stated that a construct has good reliability if the value of the Construct Reliability (CR) is $\geq 0.70$ and the extracted variance value $\geq 0.50$. Hair et al. (2016).

We processed our data using SmartPLS software version 3.2 .8 by bootstrapping 500 times.

\section{Data analysis}

The Indicators from the calculation of our first order analysis show that there is one indicator, namely the PH13, whose $t$ value is lower than 1.96 (which is, 1,321) informing that this indicator must be deleted. After the PH13

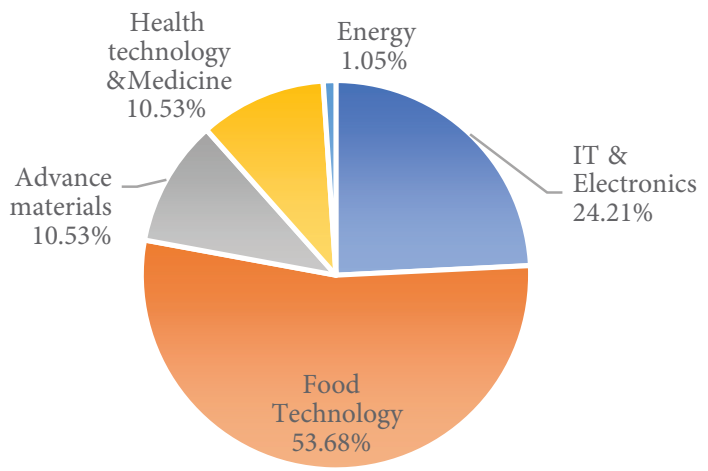

Figure 1. Industry type of the respondents

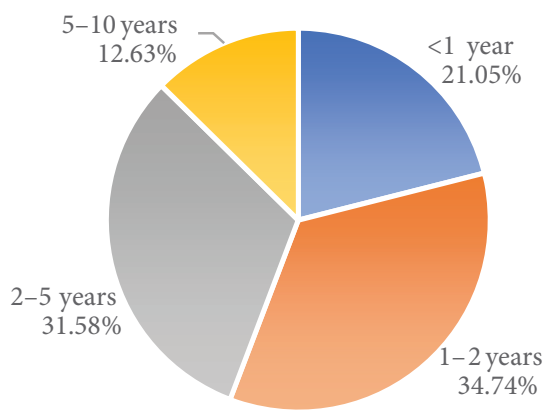

Figure 2. Business tenure of the respondents

removal was done, all the remaining indicators contained in our model have a t value greater than 1.96 and all the loading factor values are $>0.5$, which means that all remaining indicators items are significantly valid indicators of the Penta Helix construct in Figure 3.

The $t$-statistic values and also the loading factors in Figure 2 and the conclusions of the construct validity using CFA can be seen in Table 3.

Considering that the construct of the Penta Helix is an abstraction of 2 layers, a second order analysis was also carried out from the variable construct to the dimension construct. The calculation results show that all loading factor have a value that is greater than 0.5 and all values of $\mathrm{t}$-statistic are at values greater than 1.96 . These two things show that there is a Significant relationship from the latent construct to the construct of its dimension.

The second order CFA analysis in table 4 shows that the five dimensions of Penta Helix consisting of Academicians, Business, Government, Community and Medias (ABGCM) are said to be valid and Significant able to measure Penta Helix latent variables. The validity test results are also supported by the Cronbach alpha value on the Penta Helix latent variable which is at a value of 0.784 (above 0.6) and Composite Reliability which is at the number 0.828 (above 0.7 ) which shows that the instrument developed to measure this Penta Helix reliable according to the rule of thumb from (Gozali, 2008; Hair Jr et al., 2016) 


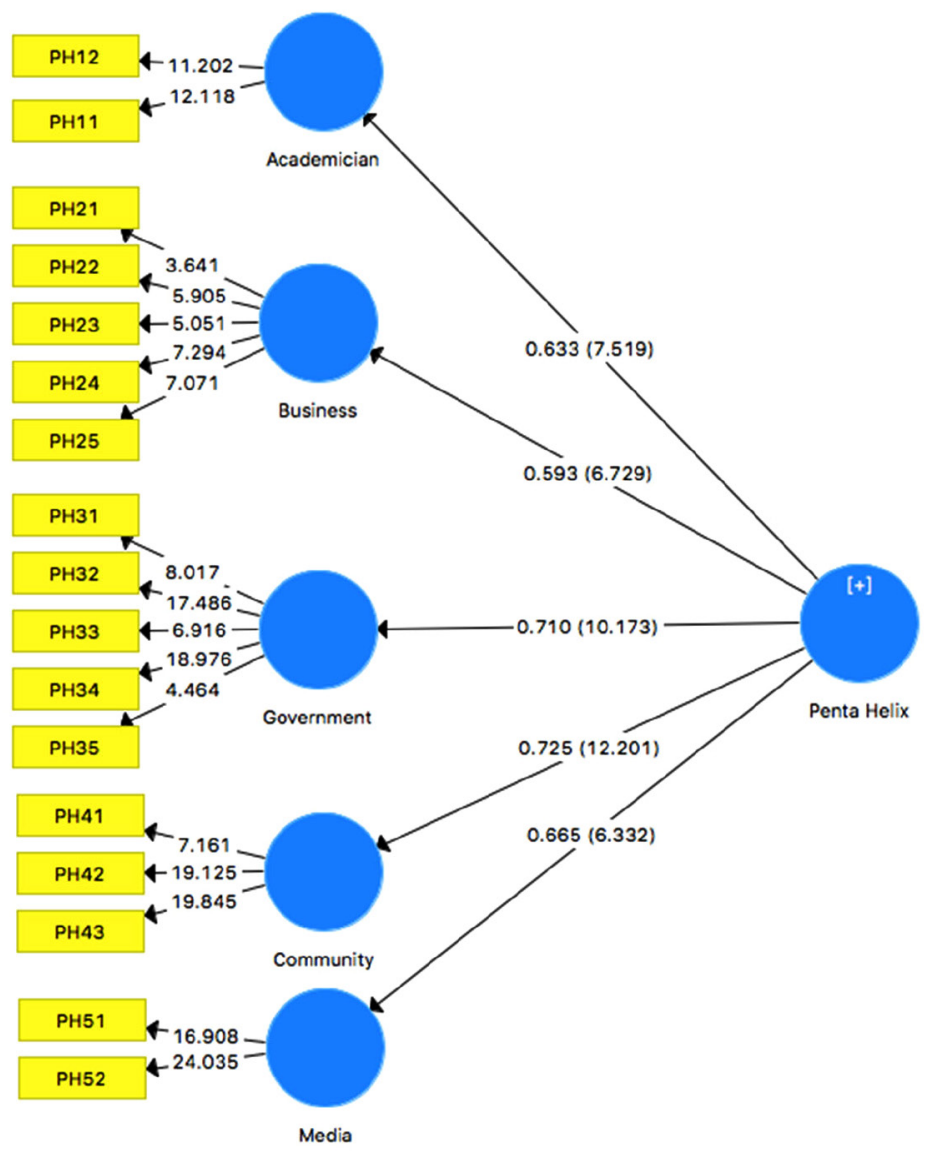

Figure 3. T-values and Path Coefficient after deletion of non-significant indicator

Table 3. Result of CFA first order analysis

\begin{tabular}{|l|c|c|c|}
\hline \multicolumn{1}{|c|}{ Item } & t-statistic & Loading Factor & Conclusion \\
\hline Academician--> PH 11 & 11.202 & 0.852 & Significant \\
\hline Academician -->PH 12 & 12.118 & 0.820 & Significant \\
\hline Business-->PH 21 & 3.641 & 0.510 & Significant \\
\hline Business -->PH 22 & 5.905 & 0.639 & Significant \\
\hline Business -->PH 23 & 5.051 & 0.575 & Significant \\
\hline Business -->PH 24 & 7.294 & 0.690 & Significant \\
\hline Business -->PH 25 & 7.071 & 0.718 & Significant \\
\hline Government-->PH 31 & 8.017 & 0.662 & Significant \\
\hline Government -->PH 32 & 17.486 & 0.803 & Significant \\
\hline Government -->PH 33 & 6.916 & 0.630 & Significant \\
\hline Government -->PH 34 & 18.976 & 0.802 & Significant \\
\hline Government -->PH 35 & 4.464 & 0.536 & Significant \\
\hline Government -->PH 41 & 7.161 & 0.636 & Significant \\
\hline Community-->PH 42 & 19.125 & 0.837 & Significant \\
\hline Community -->PH 43 & 19.645 & 0.818 & Significant \\
\hline Media -->PH 51 & 16.906 & 0.837 & Significant \\
\hline Media -->PH 52 & 24.023 & 0.858 & \\
\hline
\end{tabular}


Table 4. Results of CFA second order analysis

\begin{tabular}{|l|c|c|l|}
\hline \multicolumn{1}{|c|}{ Item } & t-statistic & Loading Factor & Conclusion \\
\hline $\begin{array}{l}\text { Penta Helix --> } \\
\text { Academician }\end{array}$ & 7.519 & 0.633 & Significant \\
\hline $\begin{array}{l}\text { Penta Helix --> } \\
\text { Business }\end{array}$ & 6.729 & 0.593 & Significant \\
\hline $\begin{array}{l}\text { Penta Helix --> } \\
\text { Government }\end{array}$ & 10.173 & 0.710 & Significant \\
\hline $\begin{array}{l}\text { Penta Helix --> } \\
\text { Community }\end{array}$ & 12.201 & 0.725 & Significant \\
\hline $\begin{array}{l}\text { Penta Helix --> } \\
\text { Media }\end{array}$ & 6.332 & 0.665 & Significant \\
\hline
\end{tabular}

Reliability test uses composite reliability (CR) and Cronbach's alpha. From the calculation result showed in Table 5 below, it can be seen that there are two constructs having a Cronbach's alpha value of less than 0.6, these indicate that those latent constructs have low reliability according to this measure according to Nunnally (1967). However, the Composite Reliability (CR) value of all latent constructs has a value greater than 0.70 and $\mathrm{CR}$ can be used as alternative to indicate reliability of the construct when Cronbach's alpha value is slightly lower than CR (Peterson \& Kim, 2013). When the CR is higher than 0.7 , it shows good reliability of the latent variables (Chin, 2010).

Table 5. Cronbach's Alpha and composite reliability

\begin{tabular}{|l|c|c|}
\hline \multicolumn{1}{|c|}{ Latent } & Cronbach's Alpha & $\begin{array}{c}\text { Composite } \\
\text { Reliability }\end{array}$ \\
\hline Penta Helix (PH) & 0.788 & 0.832 \\
\hline Academician (A) & 0.571 & 0.823 \\
\hline Business (B) & 0.592 & 0.765 \\
\hline Government (G) & 0.727 & 0.820 \\
\hline Community (C) & 0.653 & 0.811 \\
\hline Media (M) & 0.608 & 0.836 \\
\hline
\end{tabular}

\section{Discussion}

This construct is a new model in measuring the contribution of the Penta Helix ABGCM stakeholders in researches related to Innovation or Innovation Performance, where the indicators / items and dimensions measured prove to be a valid and reliable tool for measuring the support of the Penta Helix in relation with research regarding innovation. This can be considered as a separate finding because so far, the Penta Helix concept and its tools are still in the form of a conceptual framework and have never been proven with quantitative methods and empirical data.

The questionnaire set as a research tool can be said to be a reliable instrument that can be used for future research involving the Penta Helix variable in relation to Innovation.

\subsection{Theoretical contributions}

Previously, the concepts and theories regarding the Penta Helix were a conceptual framework that associated with innovation and innovation-based economics. These concept that had not been validated before, but being used by many scholars as their research framework. there are many versions of stakeholders and dimensions that made up the Penta Helix framework, but in this study the dimensions of Academic, Business, Government, Community and Medias with all the measurement indicators used in this study have proven to be valid representing the Penta Helix construct. The main contribution resulting from this research is a set of validated measurement tools of Penta Helix construct, that complements the Penta Helix theoretical framework which was initially proposed by Carayannis and Campbell (2010) and has been used by Effendi et al. (2016), Halibas et al. (2017), Muhyi et al. (2017), Tonkovic et al. (2015), E. Veckie and V. W. Veckie (2014) and several others, and can also be used as a research tool for future relevant researches.

\subsection{Methodological issue}

Based on our PLS calculation, the Penta Helix construct has an Average Variance Extracted (AVE) value of 0.444, while the rule of thumb of the AVE value is greater than 0.5 (Fornell \& Larcker, 1981). However, Ping (2009) believes others that an AVE values below 0.5 are still acceptable, especially for "new" and "interesting" research, can be accepted with the following notes:

- If the variables studied have good discriminant validity,

- if the removal of the indicator with a low loading factor is done to increase AVE, it will damage face validity and content validity, and

- written among the limitation of the study (Ping, 2009).

Ping's argument (2009) above is also in line with the argument of Boorsboom and Mellenbergh (2004) which states that there are far more important things than convergent validity, namely: (1) the suitability of the model, namely whether the construct model that is formed supports the research objectives, and (2) loading factor of latent variable forming which gives a clue about the meaning of the construct variable (Borsboom \& Mellenbergh, 2004).

The above argument becomes the basis that the construct of the Penta Helix variables still has acceptable validity, given: (1) quantitative research on the Penta helix has never been done, (20 the validity of this discriminated contract is adequate, and (2) the writer has tried to improve AVE to $>0.5$ and successfully carried out by eliminating 2 (two) dimensions namely Community helix (C) and Medias $(\mathrm{M})$, however the content validity of this study is inconsistent or incorrect, where the effect of reducing these two dimensions results in the name of the contract variable changes no longer the Penta Helix, but becomes 
Triple Helix. This becomes an argument for the use of variables and dimensions of the Penta helix construct in research even though the construct convergent validity is still said to be inadequate.

\section{Limitation and further research}

This study offers a validated construct of Penta Helix in term of innovation. However, the study still needs further investigation. First, this study involved technology-based startup founders as respondents. Even though their evaluations might represent support and relationship that they have from Penta Helix stakeholders, their subjective perceptions may differ from the respected stakeholders' perception. Future studies are suggested to involve stakeholders of Penta Helix in order to have a more comprehensive understanding of the proposed construct.

Second, further research should be conduct that links this Penta Helix construct with Innovation or Economic Performance based on innovation or other relevant matters.

Third, for future research that uses the Penta Helix construct, it is recommended to conduct a discriminant validity test as well as a convergent and internal consistency test, this is necessary to show that the research carried out has no issue in terms of the validity of the instruments used.

Forth, there is also an opportunity to make adjustments to the indicators in order to produce a construct that have a higher degree of convergent as well as discriminant validity.

\section{Conclusions}

The aim of this study was to develop constructs and measurement instruments from the Penta Helix that are validated in research related to innovation. Although there were issues arose in terms of theory development and the results of the calculation of convergent validity, the constructs and instruments can be said to be a novel contribution, since it had been developed and tested for empirical validity and can be used for measurement of the Penta Helix variables in subsequent studies. However, this construct still needs to be improved both in terms of the formation of theory and methodology or added with the next helix.

\section{References}

Afonso, O., Monteiro, S., \& Thompson, M. (2012). A growth model for the quadruple helix. Journal of Business Economics and Management, 13(5), 849-865.

https://doi.org/10.3846/16111699.2011.626438

Awaluddin, M., Sule, E. T., \& Kaltum, U. (2016). The influence of competitive forces and value creation on company reputation and competitive strategy: a case of digital creative industry in Indonesia with the implication on sustainable business performance. International Journal of Economics, Commerce and Management, $I V(2), 201-234$.
Borsboom, D., \& Mellenbergh, G. J. (2004). The concept of validity, (November). https://doi.org/10.1037/0033-295X.111.4.1061

Budiaji, W. (2013). LIKERT (The Measurement Scale and The Number of Responses in Likert Scale). Jurnal Ilmu Pertanian Dan Perikanan, 2(2), 125-131.

Calzada, I. (2016). (Un) plugging smart cities with urban transformations: towards multi-stakeholder city-regional complex urbanity. URBS. Revista de Estudios Urbanos y Ciencias Sociales, 6(2), 25-45.

Campbell, D. F. J., Carayannis, E. G., \& Rehman, S. S. (2015). Quadruple Helix structures of quality of democracy in innovation systems: the USA, OECD countries, and EU member countries in global comparison. Journal of the Knowledge Economy, 6(3), 467-493. https://doi.org/10.1007/s13132-015-0246-7

Carayannis, E. G., Barth, T. D., \& Campbell, D. F. (2012). The Quintuple Helix innovation model: global warming as a challenge and driver for innovation. Journal of Innovation and Entrepreneurship, 1(1), 2. https://doi.org/10.1186/2192-5372-1-2

Carayannis, E. G., \& Campbell, D. F. J. (2010). Triple helix, quadruple helix and quintuple helix and how do knowledge, innovation and the environment relate to each other? International Journal of Social Ecology and Sustainable Development, 1(1), 41-69. https://doi.org/10.4018/jsesd.2010010105

Chin, W. W. (2010). How to write up and report PLS analyses. In Handbook of partial least squares (pp. 655-690). Springer, Berlin, Heidelberg.

https://doi.org/10.1007/978-3-540-32827-8_29

Dhewanto, W., Hardjakaprabon, B., Lantu, D. C., Rachmawati, E., Chaerudin, R., Aina, Q., \& Herliana, S. (2014). Triple helix model in Indonesian ICT cluster development. World Applied Sciences Journal, 30(30 A), 302-307.

Effendi, D., Syukri, F., Subiyanto, A. F., \& Utdityasan, R. N. (2016). Smart city Nusantara development through the application of Penta Helix model (A practical study to develop smart city based on local wisdom). In 2016 International Conference on ICT For Smart Society (ICISS) (pp. 80-85). https://doi.org/10.1109/ICTSS.2016.7792856

Etzkowitz, H., \& Leydesdorff, L. (1997). Universities and the Global Knowledge Economy: A Triple Helix of University - Industry - Government Relations, (January 2001). SSRN.

Fathin, C. A. (2016). Analysis of three actors: roles of government, private sector, and university toward startup growth in Yogyakarta. JKAP, 20(1). https://doi.org/10.22146/jkap.10642

Fornell, C., \& Larcker, D. F. (1981). Structural equation models with unobservable variables and measurement error: Algebra and statistics. SAGE Publications Sage CA: Los Angeles, CA. https://doi.org/10.2307/3150980

Fyodorov, M. V., Peshina, E. V., Gredina, O. V., \& Avdeev, P. A. (2012). Pentahelix as a Concept of Knowledge Production in Innovative Economy. Upravlenec.

Gozali, I. (2008). Structural equation modeling: metode alternatif dengan Partial Least Square (PLS). Badan Penerbit Undip, Edisi, 2.

Guerrero, M., \& Urbano, D. (2019). A research agenda for entrepreneurship and innovation: the role of entrepreneurial universities. A Research Agenda for Entrepreneurship and Innovation, 107. https://doi.org/10.4337/9781788116015.00012

Hair Jr, J. F., Hult, G. T. M., Ringle, C., \& Sarstedt, M. (2016). A primer on partial least squares structural equation modeling (PLS-SEM). Sage publications. https://doi.org/10.15358/9783800653614

Halibas, A. S., Sibayan, R. O., Lyn, R., \& Maata, R. (2017). The Penta Helix Model of Innovation in Oman: An HEI Perspec- 
tive, (May). Interdisciplinary Journal of Information, Knowledge, and Management, 12, 159-174. https://doi.org/10.28945/3735

Ivanova, I. (2014). Quadruple helix systems and symmetry: a step towards helix innovation system classification. Journal of the Knowledge Economy, 5(2), 357-369. https://doi.org/10.1007/s13132-014-0201-z

Katili, H. W., Arbie, I. B., \& Uno, H. H. (2012). Implementing the triple helix model to expand the economy of Gorontalo province beyond natural growth and create a welfare province for all. Implementing The Triple Helix Model In a non-Western Context: an Institutional Logics Perspective, 623-631.

Latan, H., \& Ghozali, I. (2012). Partial least squares: concepts, techniques and applications using SmartPLS 3. Research Gate.

Leydesdorff, L. (2012a). The triple helix, quadruple helix, ... , and an n-tuple of helices: explanatory models for analyzing the knowledge-based economy? Journal of the Knowledge Economy, 3, 25-35. https://doi.org/10.1007/s13132-011-0049-4

Leydesdorff, L. (2012b). The Triple Helix of University-IndustryGovernment Relations. Scientometrics, 58, 191-203.

Leydesdorff, L., \& Park, H. W. (2014). Can synergy in triple-helix relations be quantified? A review of the development of the triple-helix indicator. Triple Helix, 1(4), 1-22. https://doi.org/10.2139/ssrn.2377307

Lindtner, S., Hertz, G. D., \& Dourish, P. (2014). Emerging sites of HCI innovation. Proceedings of the 32nd Annual ACM Conference on Human Factors in Computing Systems - CHI '14, 439-448. https://doi.org/10.1145/2556288.2557132

Muhyi, H. A., Chan, A., Sukoco, I., \& Herawaty, T. (2017). The Penta Helix Collaboration Model in Developing Centers of Flagship Industry in Bandung City. Review of Integrative Business \& Economics Research, 6(1).

Nylander, S., \& Tholander, J. (2017). Community-based innovation among elite orienteers. In Proceedings of the 8th International Conference on Communities and Technologies (pp. 87-95).
Nunnally, J. C., \& Bernstein, I. H. (1967). McGraw-Hill series in psychology. Psychometric theory. New York, NY, US: McGrawHill.

Parveen, S., Senin, A. A., \& Umar, A. (2015). Organization culture and open innovation: A Quadruple Helix Open Innovation Model Approach. International Journal of Economics and Financial Issues, 5(2), 335-342.

Ping, R. A. (2009). Is there any way to improve Average Variance Extracted (AVE) in a Latent Variable (LV) X (Revised)? http://Www.Wright.Edu/ robert.Ping/ImprovAVE2.Doc

Rampersad, G., Quester, P., \& Troshani, I. (2010). Managing innovation networks: Exploratory evidence from ICT, biotechnology and nanotechnology networks. Industrial Marketing Management, 39(5), 793-805.

https://doi.org/10.1016/j.indmarman.2009.07.002

Ranga, M., \& Etzkowitz, H. (2013). Triple Helix systems: an analytical framework for innovation policy and practice in the Knowledge Society. Industry and Higher Education, 27(4). https://doi.org/10.5367/ihe.2013.0165

Sharma, S., \& Sharma, S. (1996). Applied multivariate techniques. Wiley. ISBN: 978-0-471-31064-8

Spender, J.-C., Corvello, V., Grimaldi, M., \& Rippa, P. (2017). Startups and open innovation: a review of the literature. European Journal of Innovation Management, 20(1), 4-30. https://doi.org/10.1108/EJIM-12-2015-0131

Tonkovic, A. M., Veckie, E., \& Veckie, V. W. (2015). Aplications of penta helix model in economic development. Economy of Eastern Croatia Yesterday, Today, Tommorow, 4.

Tonkovic, A. M., Veckie, E., Veckie, V. W., \& others. (2015). Aplications of Penta Helix Model in Economic Development. IDEAS.

Veckie, E., \& Veckie, V. W. (2014). Aplications of Penta Helix model in economic development. Economy of Eastern Croatia Yesterday, Today, Tommorow, 4, 385-393.

Yahya, M. P., Santoso, B., \& Wanto, A. H. (2018). Implementasi Bantuan Pemerintah dalam Kementrian Koperasi dan UKM (Studi Pada Kabupaten Lombok Tengah). Jurnal Profit, 12(2), 31-38. 


\section{APPENDIX}

\section{Questionnaire}

\begin{tabular}{|c|c|c|}
\hline No & Item & t-statistics \\
\hline PH 11 & $\begin{array}{l}\text { How is the quality and availability of workforce that graduated from the local Higher } \\
\text { Education Institutions who works at your startup? }\end{array}$ & 11.202 \\
\hline PH 12 & $\begin{array}{l}\text { To what extent does your Startup utilize research results from the local Higher Education } \\
\text { Institutions? }\end{array}$ & 12.118 \\
\hline PH 13 & $\begin{array}{l}\text { How far is the location between the Science and Technology Centres Area where your } \\
\text { startup is located from the local Higher Education Institutions? }\end{array}$ & - \\
\hline PH 21 & To what extent does your Startup utilize bank loans as capital? & 3.641 \\
\hline PH 22 & How often does your startup have an investment partnership with other businesses? & 5.905 \\
\hline PH 23 & How often does your startup perform business interactions with other companies? & 5.051 \\
\hline PH 24 & $\begin{array}{l}\text { How often does your startup get guidance / sharing experiences / knowledge from } \\
\text { established business people? }\end{array}$ & 7.294 \\
\hline PH 25 & $\begin{array}{l}\text { How often does your startup get CSR fund or benefit from programs from large } \\
\text { companies? }\end{array}$ & 7.071 \\
\hline PH 31 & What do you think about the ease of the startup licensing process in your region? & 8.017 \\
\hline PH 32 & In your opinion, how does government policy support startups? & 17.486 \\
\hline PH 33 & Taxation and user charges are easy to deal with and are not burdensome & 6.916 \\
\hline PH 34 & Government assistances are available and easily accessible & 18.976 \\
\hline PH 35 & The quality of basic infrastructure at STP such as electricity, roads, water is good enough. & 4.464 \\
\hline PH 41 & My product is consumed by the community I targeted & 7.161 \\
\hline PH 42 & Startups get lots of ideas and information from the community & 19.125 \\
\hline PH 43 & We get a lot of human resources and other needs from our community & 19.645 \\
\hline PH 51 & We get lots of ideas, input and other valuable information from medias & 16.906 \\
\hline PH 52 & The mass media publicize many of our products and businesses & 24.023 \\
\hline
\end{tabular}

Items with - sign under the t statistic column are deleted in the prespecified model due to non-significant val. 